DOI

\title{
ЗАСТОСУВАННЯ МЕЛЬДОНІЮ В РЕАБІЛІТАЦІЇ ХВОРИХ НА ХРОНІЧНИЙ ПАНКРЕАТИТ У ПОЄДНАННІ ІЗ СТАБІЛЬНОЮ ІШЕМІЧНОЮ ХВОРОБОЮ СЕРЦЯ
}

\author{
๑Л. С. Бабінець, Н. А. Мельник, І. О. Гніздюх, Л. В. Доброродня
}

ДВНЗ «Тернопільський державний медичний університет імені І.Я. Горбачевського МОз України»

РЕзюмЕ. Один із небагатьох способів відновлення нормальної роботи всіх життєво важливих органів і систем - це застосування метаболічної терапії.

Метою роботи було дослідити ефективність курсового лікування метаболічним препаратом Мельдоній для корекції прооксидатно-антиоксидантних і трофологічних порушень у хворих з коморбідним перебігом хронічного панкреатиту (XП) та стабільної ішемічної хвороби серця (CIXC).

Матеріал і методи. У дослідження включено 90 пацієнтів із ХП в поєднанні із СІХС, яких було поділено на дві групи (залежно від програм лікування): І група (45 хворих) отримувала загальноприйняте лікування (ЗПЛ); II група (45 хворих) - окрім ЗПЛ додатково отримувала ступінчастий курс препарату мельдонію (Вазонат) за наступною схемою: перший ступінь - по 5 мл в/в струминно 1 раз на день протягом 10 днів; другий ступінь введення мельдонію електрофорезом на ділянку лівого підребер'я через день впродовж 15 днів; третій ступінь - подальший прийомом препарату по 2 капсули 1 раз на день впродовж місяця.

Результати. Було доведено, що додавання до комплексної терапії хворих із коморбідністю ХП та СІХС препарату Мельдонію більшою мірою сприяє поліпшенню показників трофологічного і прооксидатноантиоксидантного статусу, ніж при стандартній базисній терапії.

КЛючовІ СлОВА:хронічний панкреатит; стабільна ішемічна хвороба серця; метаболічна терапія; мельдоній; ступінчасте введення.

Вступ. ХП є одним з найпоширеніших захворювань підшлункової залози (ПЗ) із високим рівнем випадків тимчасової непрацездатності й первинної інвалідизації (до 15,0 \%), що характеризується прогресуючим перебігом із наростанням функціональної недостатності ПЗ, розвитком порушень у прооксидантно-антиоксидантній системі та виникненням трофологічної недостатності (TH) $[1,2]$.

ТН, яка виникає при ХП, характеризується синдромами дефіциту енергії, білка, вітамінів, мікроелементів і електролітів, а саме: білковою недостатністю, вторинним імунодефіцитом, остеопоротичними явищами, анемією тощо [3]. На тлі прогресуючої функціональної недостатності ПЗ і поглиблення ТН вичерпуються запаси нутрієнтів у тканинах, що спочатку призводить до біохімічних і функціональних змін, а згодом проявляється численними та складними клінічними симптомами [4]. Розвиток ТН сприяє прогресуванню ХП та розвитку його ускладнень. При сформованій ТН виникає дефіцит мікроелементів і вітамінів, що лежить в основі зниження функції антиоксидантної системи (АОС). При ХП відбувається активація перекисного окиснення ліпідів (ПОЛ), потенціюється хронічний запальний процес у тканині залози, що призводить до прогресування фіброзу і атрофії паренхіми [5].

У хворих з коморбідним перебігом ХП та СІХC розвивається недостатність АОС з одночасною активацією ПОЛ. Також наявність і глибина порушень у прооксидантно-антиоксидантній системі значною мірою визначають тяжкість перебігу за- хворювання. При оксидативному стресі вільні радикали блокують обмін речовин у ацинарних клітинах, розплавляють лізосомні гранули та гранули зимогену, окиснюють ліпіди клітинних мембран, унаслідок чого починається запальна реакція, що, в свою чергу, активує панкреатичні проферменти [6].

Відомо про негативний вплив ХП на серцевосудинну систему. Встановлено, що у 15,5 \% хворих із гастроентерологічними патологіями, в тому числі з панкреатитами, має місце СІХC. До сьогодні досконало ще не вивчені механізми реалізації впливу запального процесу в ПЗ на розвиток та прогресування СІХC [7]. Поєднання ХП та СІХС призводить до ряду структурних і метаболічних змін, що впливають на перебіг обох захворювань, та зумовлює необхідність розробки системного підходу до вивчення зазначених порушень у цієї групи пацієнтів [8]. Невизначеність цих механізмів залишає відкритим питання медикаментозної терапії такого контингенту хворих, що в цілому знижує ефективність лікування хворих на CIXC. Тому пошук ефективних схем лікування у цьому напрямку $\epsilon$ актуальним для сучасної медицини $[9,10]$.

Стандартна базисна терапія коморбідності ХП та СІХС не включає корекції трофологічних і прооксидантно-антиоксидантних розладів [11]. Останніми роками у лікарській практиці стали активно призначати метаболічні препарати. Мельдоній, як представник препаратів метаболічної терапії, належить до парціальних інгібіторів окиснення жирних кислот. Механізм його дії 
Огляди літератури, оригінальні дослідження, погляд на проблему

пов'язаний із зворотним обмеженням швидкості біосинтезу карнітину із його попередника - гамма-бутиробетаїну. Внаслідок цього гальмується карнітин-опосередкований транспорт довголанцюгових жирних кислот через мембрани мітохондрій без впливу на метаболізм коротколанцюгових жирних кислот, завдяки чому мельдоній здатний впливати на зміни в трофологічному та прооксидантно-антиоксидантному статусах.

Отже, застосування метаболічних препаратів у стандартній базисній терапії при коморбідності XП та СІXC $\epsilon$ найдоцільнішим та патогенетично обґрунтованим.

Метою дослідження було дослідити ефективність лікування метаболічним препаратом мельдонію (Вазонат) зі ступінчастим шляхом введення при корекції прооксидатно-антиоксидантних і трофологічних порушень у хворих з коморбідним перебігом ХП та СІХC.

Матеріал і методи дослідження. Для досягнення поставленої мети було відібрано 90 Хворих на ХП із супутньою СІХС (стенокардія напруги I-II функціонального класу), які лікувалися в денному стаціонарі Тернопільської міської клінічної лікарні № 2. Серед них було 46 (51,2 \%) чоловіків віком $(49,9 \pm 8,7)$ років та 44 жінки $(48,8 \%)$ віком $(52,7 \pm 6,2)$ років. У дослідження не включали пацієнтів із гострими формами IXC в анамнезі, інсулінозалежним ЦД, ЦД з тяжким перебігом, нестабільною стенокардією, тяжкою артеріальною гіпертензією, тяжкими порушеннями ритму серця та тяжкими супутніми захворюваннями.

Залежно від програм лікування хворих було поділено на дві групи: I група (45 хворих) отримувала загальноприйняте лікування (ЗПЛ) (нітрати, бета-блокатори, інгібітори ангіотензинперетворювального ферменту, антагоністи рецепторів ангіотензину II, антагоністи кальцію, статини, антиагреганти, спазмолітики, прокінетики, інгібітори протонної помпи, ферментні засоби); ІІ група (45 хворих) окрім ЗПЛ додатково отримувала препарат мельдонію (Вазонат) за ступінчастою схемою введення: перший ступінь - по 5 мл в/в струминно 1 раз на день впродовж 10 днів; другий ступінь - подальше введення мельдонію електрофорезом на ділянку лівого підребер'я через день впродовж 15 днів; третій ступінь - наступний прийом препарату по 2 капсули 1 раз на день впродовж місяця. Мельдоній-електрофорез виконували традиційним методом з біполярним введенням препарату за допомогою двоканального апарата «Поток-1», використовуючи гальванічний струм. Електроди при цьому розміщували поперечно, вздовж лівої реберної дуги (оскільки ця зона відповідає проекції підшлункової залози на передню черевну стінку) на відстані 10 см один від одного. Тривалість процедури становила 20 хв. Контрольну групу склали 20 практично здорових осіб віком від 19 до 46 років, середній вік $(32,2 \pm 1,8)$ років. Серед них було 11 (55 \%) чоловіків та 9 (45\%) жінок.

Діагноз ХП верифікували згідно із загальноприйнятими в клініці критеріями. Діагноз СІХC встановлювали згідно із рекомендаціями міжнародної класифікації хвороб 10 перегляду, відповідно до класифікації, яка була затверджена Наказом МОЗ України № 152 від 02.03.2016. Функціональний клас стенокардії напруги - за класифікацією стенокардії Канадської асоціації кардіологів (1976) та за показниками велоергометрії.

Про стан ПОЛ та АОЗ до та після лікування судили за рівнями малонового альдегіду (МА), супероксиддисмутази (СОД), SH-груп, каталази та церулоплазміну (ЦП) крові.

Активність СОД визначали на підставі ії здатності конкурувати з нітротетразолієм синім за супероксидні аніони, які утворюються внаслідок аеробної взаємодії відновленої форми НАДН 2 та феназинметасульфату. Кількість ферменту визначали спектрометричним методом. За норму вважали показник $(62,15 \pm 2,82)$ ум. од.

Рівень каталазної активності визначали за допомогою здатності перекису водню утворювати з молібдатом амонієм стійкий забарвлений комплекс, інтенсивність забарвлення якого залежить від активності каталази у пробі. Норма каталазної активності в крові становить $(17,48 \pm 0,87) \%$.

Рівні SH-груп, ЦП та MA визначали за методами Бойера, Х. Д. Равіна та В. Н. Орехович з тіобарбітуратовою кислотою відповідно. Норма SH-груп крові - $(60,5 \pm 2,13)$ ммоль/л, МА $(2,810 \pm 0,085)$ мкмоль/л, а кількість ЦП в нормі не повинна перевищувати 300 мг/л.

Для оцінки трофологічного статусу до та після лікування хворих на ХП в поєднанні із СІХС використовували визначення наступних показників: гемоглобіну (Hb), еритроцитів (Eг), загального білка (3Б), сироваткових трансферину (ТС) та феритину (ФС).

Рівень Нb визначали фотометричним методом, а кількість Ег в крові - рутинним методом. Нормою вважають не менше ніж 120 г/л для чоловіків і 110 г/л для жінок та 4,0-5,0×1012/л для чоловіків і $3,7-4,7 \times 10^{12} /$ л для жінок відповідно. ЗБ у крові визначали за загальноприйнятою методикою, нормою вважали 65-85 г/л. Нормальні значення ФС та ТС в сироватці крові становлять 10,0147,0 нг/мл - для жінок та 22,0-346,0 нг/мл - для чоловіків і 215,0-380,0 мг/дл - для жінок та чоловіків відповідно. 
Огляди літератури, оригінальні дослідження, погляд на проблему

Статистичну обробку отриманих даних виконували на персональному комп'ютері з використанням пакетів програм Microsoft Excel та Statistica for Windows версіï 6.0 (Stat Soft inc., США). Достовірність різниці середніх значень визначали з обчисленням U-критерію Манна-Уїтні $(p<0,05)$.

Результати й обговорення. При дослідженні стану показників синдрому ПОЛ і АОС до лікування у хворих на ХП в поєднанні із СІХС було виявлено, що рівень МА як маркера інтенсифікації поЛ був достовірно вищим у I та II досліджуваних групах, порівняно з контролем, і становив відповідно $(6,35 \pm 0,07)$ мкмоль/л та $(6,39 \pm 0,09)$ мкмоль/л. Після проведеного лікування рівень МА в I групі достовірно знизився на 1,40 мкмоль/л (22,05 \%), тоді як в II групі цей показник достовірно знизився на 2,22 мкмоль/л (34,75 \%), що вказувало на більш значне пригнічення прооксидантних механізмів під впливом прийому мельдонію, порівняно із результатами традиційного лікування.

Також до лікування відмічалося достовірне зниження активності ферментів AOC за рівнем СОД (I група - $(39,22 \pm 0,47)$ ум. од; II група $(39,52 \pm 0,45)$ ум. од.) та SН-груп (I група $(38,55 \pm 0,47)$ ммоль/л; II група- $(38,52 \pm 0,45)$ ммоль/л) в обох досліджуваних групах порівняно із контролем. Після проведеного лікування простежувалося більш значне достовірне зростання активності СОД (на 24,98\%) та підвищення рівня SH-груп (на 15,81\%) у II групі, тоді як у I групі ці показники зростали незначно та недостовірно.
Рівень каталази в плазмі крові до лікування у I та II групах хворих був достовірно вищим, порівняно із контролем $((55,72 \pm 1,12) \%$ та $(55,77 \pm 1,03) \%$ відповідно). Після проведеного лікування цей показник достовірно знизився на 16,22 \% у I групі та на 30,68 \% у II групі, що засвідчило регулювальну здатність мельдонію відносно АОЗ. Щодо рівня ЦП крові в I та II групах, то цей показник був підвищений порівняно з контролем; після лікування рівень ЦП достовірно знизився у двох досліджуваних групах (на 13,18 \% у I групі та на 23,48 \% у II групі), що довело протизапальні та коригувальні властивості мельдонію за ступінчастим шляхом введення при досліджуваній поєднаній патології (табл. 1).

Аналізуючи отримані дані, наведені на рисунку 1, можна констатувати вищу ефективність запропонованої схеми лікування, підсиленої використанням мельдонію зі ступінчастим шляхом введення, порівняно з загальноприйнятою терапією. Рівень ЗБ крові після проведеного лікування зростав у I групі на 3,41 г/л - 5,4 \%; у II групі - на 7,90 г/л - 13,8 \%, що на 8,4 \% вище порівняно 3 аналогічним показником у I групі. Також встановлено достовірне зростання рівня $\mathrm{Hb}$ в I групі 3 $(101,17 \pm 1,87)$ г/л до $(107,58 \pm 1,28)$ г/л та рівня Ег крові (на 8,48 \%), тоді як у II групі спостерігався більш значний приріст як рівня $\mathrm{Hb} 3$ $(100,64 \pm 0,55)$ г/л до $(118,38 \pm 1,23)$ г/л, так і рівня $\mathrm{Er}$ крові (на 19,69\%).

Про вищу ефективність схеми лікування хворих на ХП в поєднанні із СІХC, посиленої ступене-

Таблиця 1. Стан показників системи ПОЛ/АОЗ у хворих на ХП із супутньою СІХС до та після лікування у порівнюваних групах

\begin{tabular}{|c|c|c|c|c|c|}
\hline \multirow{2}{*}{ Показник ПОЛ/АОЗ } & \multirow{2}{*}{$\begin{array}{l}\text { Контрольна } \\
\text { група }(n=20)\end{array}$} & \multicolumn{2}{|c|}{$\begin{array}{c}\text { І група } \\
(\mathrm{n}=45)\end{array}$} & \multicolumn{2}{|c|}{$\begin{array}{c}\text { II група } \\
(\mathrm{n}=45)\end{array}$} \\
\hline & & до лікування & після лікування & до лікування & після лікування \\
\hline МА, мкмоль/л & $2,18 \pm 0,09$ & $\begin{array}{l}6,35 \pm 0,07 \\
{ }^{*} \mathrm{p}<0,001\end{array}$ & $\begin{array}{l}4,95 \pm 0,12 \\
* * p<0,01\end{array}$ & $\begin{array}{l}6,39 \pm 0,09 \\
{ }^{*} p<0,001\end{array}$ & $\begin{array}{l}4,17 \pm 0,15 \\
* * p<0,001 \\
* * * p<0,001\end{array}$ \\
\hline SH-групи, ммоль/л & $68,50 \pm 2,13$ & $\begin{array}{c}38,55 \pm 0,47 \\
{ }^{*} \mathrm{p}<0,001\end{array}$ & $\begin{array}{c}40,33 \pm 0,84 \\
* * p>0,05\end{array}$ & $\begin{array}{c}38,52 \pm 0,45 \\
{ }^{*} p<0,001\end{array}$ & $\begin{array}{c}44,61 \pm 0,22 \\
* * p<0,01 \\
* * * p<0,05\end{array}$ \\
\hline СОД, ум.од. & $62,15 \pm 2,85$ & $\begin{array}{c}39,22 \pm 0,47 \\
{ }^{*} p<0,001\end{array}$ & $\begin{array}{c}42,37 \pm 0,53 \\
* * p>0,05\end{array}$ & $\begin{array}{c}39,52 \pm 0,45 \\
{ }^{*} p<0,001\end{array}$ & $\begin{array}{c}49,39 \pm 0,31 \\
* * p<0,01 \\
* * * p<0,05\end{array}$ \\
\hline Каталаза,\% & $17,48 \pm 0,87$ & $\begin{array}{c}55,72 \pm 1,12 \\
{ }^{*} \mathrm{p}<0,001\end{array}$ & $\begin{array}{c}46,69 \pm 0,41 \\
* * 0<0,01\end{array}$ & $\begin{array}{c}55,77 \pm 1,03 \\
{ }^{*} p<0,001\end{array}$ & $\begin{array}{l}38,66 \pm 0,32 \\
* * p<0,001 \\
* * * p<0,01\end{array}$ \\
\hline ЦП, мг/л & $245,6 \pm 2,6$ & $\begin{array}{l}591,1 \pm 6,0 \\
{ }^{*} p<0,001\end{array}$ & $\begin{array}{l}512,0 \pm 5,9 \\
* * p>0,05\end{array}$ & $\begin{array}{l}593,1 \pm 5,1 \\
{ }^{*} p<0,001\end{array}$ & $\begin{array}{l}453,8 \pm 5,1 \\
* * p<0,01 \\
* * * p>0,05\end{array}$ \\
\hline
\end{tabular}

Примітки: 1. * - вірогідність різниці стосовно таких показників групи контролю;

2. ** - вірогідність різниці стосовно таких показників своєї групи хворих на ХП+СІХС до лікування;

3. *** - достовірність різниці стосовно таких показників І групи хворих. 


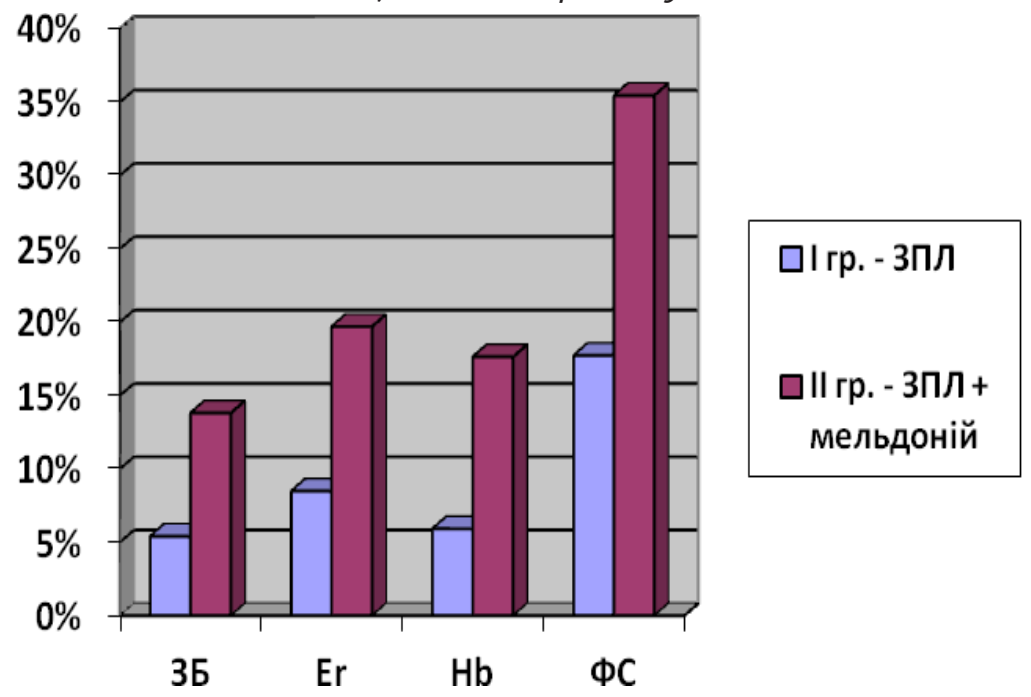

Рис. 1. Відсотковий приріст показників трофологічного статусу у хворих із коморбідністю ХП та СІХС у порівнюваних групах після лікування

вим використанням мельдонію, можна судити за рівнями ТС та ФС. Рівень ТС до лікування у I групі становив - $(532,22 \pm 16,17)$ мг/дл, у II групі $(527,99 \pm 19,72)$ мг/дл. Після проведеного лікування цей показник знизився на 8,71 \% - в І групі і на 15,11 \% - в II групі. Також відмічалося підвищення рівня ФС у I та II досліджуваних групах (на 17,72 \% та 35,45 \% відповідно), проте приріст даного показника в II групі був більш значущим, що ще раз підкреслює ефективність і доцільність використання метаболічної терапії за ступінчастим введенням у хворих з коморбідним перебігом ХП та СІХC.

Висновки. Використання в комплексному лікуванні хворих на ХП у поєднанні із СІХС метаболічного препарату мельдонію 3 ступінчастим шляхом введенням сприяло більш достовірному регресу прооксидантно-антиоксидантних порушень, порівняно із стандартною загальноприйнятою терапією. Додавання до комплексної терапії хворих із коморбідним перебігом ХП та СІХC препарату мельдонію за ступінчастим шляхом введення привело до більш значного покращення показників трофологічного статусу за дослідженими параметрами $(p<0,05)$, ніж при стандартній базисній терапії.

Перспективи подальших досліджень - планується вивчити вплив запропонованих програм лікування на показники калікреїн-кінінової системи хворих на хронічний панкреатит із супутньою стабільною ішемічною хворобою серця.

\section{ЛІТЕРАТУРА}

1. Бабінець Л. С. Патогенетичні аспекти хронічного панкреатиту міліарного генезу після холецистектомії / Л. С. Бабінець // Вестник клуба панкреатологов. - 2014. № 3. - С. 24-30.

2. Бабінець Л. С. Вітамінний і антиоксидантний дисбалансу клінічній картині хронічного панкреатиту у практиці сімейного лікаря / Л. С. Бабінець, І. М. Галабіцька, А. І. Бабінець // Сімейна медицина. - 2014. - № 1 (51). - С. 122-124.

3. Особливості анемічного синдрому як прояву трофологічної недостатності при хронічному панкреатиті на тлі ішемічної хвороби серця / Л. С. Бабінець, Н. А. Мельник, Л. С. Цибульська, М.В.Скрипник // Здобутки клінічної та експериментальної медицини. 2016. - № 2 (26). - С. 29-32.

4. Губергриц Н. Б. Показатели ультразвуковой гистографии поджелудочной железы в динамике лечения больных с хроническим панкреатитом на фоне ожирения / Н. Б. Губергриц, О. А. Бондаренко // Гастроентерологія. - 2013. - № 2. - С. 64-67.
5. Христич Т. М. Хронічний панкреатит у геріатричних хворих: особливості клінічного перебігу, стану пероксидації ліпідів та антиоксидантної системи / Т. М. Христич // Вісник наукових досліджень. - 2015. - № 4. - С. 42-44.

6 . The prevalence of malnutrition and fat-soluble vitamin deficiencies in chronic pancreatitis / S. N. Duggan, N. D. Smyth, M. O'Sullivan [et al.] // Nutr. Clin. - 2014. - № 29.- P. 48-54.

7. Винокуров М. М. Прогностическое значение состояния прооксидантной и антиоксидантной систем организма у больных со стерильным панкреонекрезом / М. М. Винокуров, В. В. Савельев // Хирургия. - 2014. № 12. - С. 38-52.

8. Архій Е. Й. Особливості змін процесів травлення, лабораторних та імунологічних показників при хронічних захворюваннях підшлункової залози, поєднаних з IXC та захворюваннями гепатобіліарної системи / Е. Й. Архій, Т. В. Мишанич, О. М. Москаль // Гастроентерологія. - 2012. - Вип. 46. - С. 56-62. 
Огляди літератури, оригінальні дослідження, погляд на проблему

9. Patients with exocrin einsufficiency due to chronic pancreatitis are undertreated: a Dutch national survey / E. C. Sikkens, D. L. Cahen, C. Van Eijck [et al.] // J. Pancreatol. Official J. Int. Assoc. Pancreatol. - 2012. - № 12. - P. 71-73. 10. Schneider $A$. The M-ANNHEIM classification of chronic pancreatitis: introduction of a unifying

classification system based on a review of previous classifications of the disease / A. Schneider, J. M. Löhr, M. V. Singer // J. Gastroenterol.-2014. - № 42. -P. 101-119.

11. Губергиц Н. Б. Клическая панкреатология / Н. Б. Губергриц, Т. М. Христич. - Донецк : ООО «Лебедь», 2013. - С. 236.

\section{REFERENCES}

1. Babinets, L.S. (2014). Patohenetychni aspekty khronichnoho pankreatytu biliarnoho henezu pislia kholetsystektomii [Pathogenetic aspects of chronic pancreatitis of biliary origin after cholecystectomy]. Vestnyk kluba pankreatolohov - Journal of Pancreatologists' Club, 3, 24-30 [in Ukrainian].

2. Babinets, L.S., Halabitska, I.M., \& Babinets, A.I. (2014). Vitaminnyi i antyoksydantnyi dysbalans u klinichniy kartyni khronichnoho pankreatytu u praktytsi simeinoho likaria [Vitamin and antioxidant imbalance in the clinical picture of chronic pancreatitis in the practice of a family doctor]. Simeina medytsyna - Family Medicine, 1 (51), 122124 [in Ukrainian].

3. Babinets, L.S., Melnyk, N.A., Tsybulska, L.S., \& Skrypnyk, M.V. (2016). Osoblyvosti anemichnoho syndromu yak proiavu trofolohichnoi nedostatnosti pry khronichnomu pankreatyti na tli ishemichnoi khvoroby sertsia [Features of anemic syndrome as a manifestation of trophologic insufficiency in chronic pancreatitis against the background of ischemic heart disease]. Zdobutky klinichnoi ta eksperymentalnoi medytsyny - Achievements of Clinical and Experimental Medicine, 2 (26), 29-32 [in Ukrainian].

4. Huberhryts, N.B., \& Bondarenko, O.A. (2013). Pokazateli ultrazvukovoy gistografii podzheludochnoy zhelezy $v$ dinamike lecheniya bolnykh $s$ khronicheskym pankreatitom na fone ozhyreniya [Indicators of ultrasonic gistography of pancreatic gland in the dynamics of treatment of patients with chronic pancreatitis on the background of obesity]. Hastroenterolohiia - Gastroenterology, 2, 64-67 [in Russian].

5. Khrystych, T.M. (2015). Khronichnyi pankreatyt u heriatrychnykh khvorykh: osoblyvosti klinichnoho perebihu, stanu peroksydatsii lipidiv ta antyoksydantnoi systemy [Chronic pancreatitis in geriatric patients: clinical course, the state of lipid peroxidation and antioxidant

system]. Visnyk naukovykh doslidzhen - Journal of Scientific Researches, 4, $42-44$ [in Ukrainian].

6. Duggan, S.N., Smyth, N.D., O'Sullivan, M., Feehan, S., Ridgway, P.F., \& Conlon, K.C. (2014). The prevalence of malnutrition and fat-soluble vitamin deficiencies in chronic pancreatitis. Nutr. Clin., 29, 48-54.

7. Vynokurov, M.M., \& Savelev, V.V. (2014). Prognosticheskoe znachenie sostoyaniya prooksydantnoy i antyoksydantnoy system organizma u bolnykh so sterilnym pankreonekrezom [Prognostic value of the state of the prooxidant and antioxidant systems of the organism in patients with sterile pancreatonecrease]. Khirurgiya Surgery, 12, 38-52 [in Russian].

8. Arkhiy, E.Y., Myshanych, T.V., \& Moskal, O.M. (2012). Osoblyvosti zmin protsesiv travlennia, laboratornykh ta imunolohichnykh pokaznykiv pry khronichnykh zakhvoriuvanniakh pidshlunkovoi zalozy poiednanykh z IKhS ta zakhvoriuvanniamy hepatobiliarnoi systemy [Specificity of the process of etching, laboratory and immunologic displays when chronic diseases of pancreas combined with IHD and diseases of hepatobiliary system]. Hastroenterolohiia - Gastroenterology, 46, 56-62 [in Ukrainian].

9. Sikkens, E.C., Cahen, D.L., Van Eijck, C., Kuipers, E.J., \& Bruno, M. (2012). Patients with exocrin einsufficiency due to chronic pancreatitis are undertreated: a Dutch national survey. J. Pancreatol. Official J. Int. Assoc. Pancreatol., 12, 71-73.

10. Schneider, A., Löhr, J.M., \& Singer, M.V. (2014). The M-ANNHEIM classification of chronic pancreatitis: introduction of a unifying classification system based on a review of previous classifications of the disease. $J$. Gastroenterol., 42, 101-119.

11. Huberhyts, N.B., \& Khrystych, T.M. (2013). Klycheskaya pankreatologiya [Clinical pancreatology]. Donetsk: OOO «Lebed» [in Russian]. 
Огляди літератури, оригінальні дослідження, погляд на проблему

ПРИМЕНЕНИЕ МЕЛЬДОНИЯ В РЕАБИЛИТАЦИИ БОЛЬНЫХ ХРОНИЧЕСКИМ ПАНКРЕАТИТОМ В СОЧЕТАНИИ СО СТАБИЛЬНОЙ ИШЕМИЧЕСКОЙ БОЛЕЗНЬЮ СЕРДЦА

\author{
๑Л. С. Бабинец, Н. А. Мельник, И. О. Гниздюх, Л. В. Доброродня
}

ГВУз «Тернопольский государственный медицинский университет имени И. Я Горбачевского МЗ Украины»

РЕЗЮМЕ. Один из немногих способов восстановления нормальной работы всех жизненно важных органов и систем - это применение метаболической терапии.

Целью работы было исследовать эффективность курсового лечения метаболическим препаратом Мельдоний на коррекциюпрооксидатно-антиоксидантныхитрофологичнихнарушений у больныхскоморбидным течением хронического панкреатита (ХП) и стабильной ишемической болезни сердца (СИБС).

Материал и методы. В исследование включили 90 пациентов с ХП в сочетании с СИБС, которые были разделены на две группы (в зависимости от программы лечения): I группа (45 больных) получала общепринятое лечение (ОПЛ); II группа (45 больных) кроме ОПЛ, дополнительно получала ступенчатый курс препарата мельдоний (Вазонат) по следующей схеме: первая степень - по 5 мл в/в болюсно 1 раз в день в течение 10 дней; вторая степень - введение мельдоний-электрофореза на область левого подреберья через день в течение 15 дней; третья степень - дальнейший прием препарата по 2 капсулы 1 раз в день в течение месяца.

Результаты. Было доказано, что добавление к комплексной терапии больных с коморбидностю ХП и СИБС препарата мельдоний в большей степени способствует улучшению показателей трофологического и прооксидатно-антиоксидантного статуса, чем при стандартной базисной терапии.

КЛЮчЕВЫЕ СЛОВА: хронический панкреатит; стабильная ишемическая болезнь сердца; метаболическая терапия; мельдоний; ступенчатое введение.

\title{
MELDONIUM APPLICATION IN REHABILITATION OF PATIENTS WITH CHRONIC PANCREATITIS COMBINED WITH STABLE CORONARY ARTERY DISEASE
}

\author{
@L. S. Babinets, N. A. Melnyk, I. O. Hnizdiukh, L. V. Dobrorodnia \\ I. Horbachevsky Ternopil State Medical University
}

SUMMARY. One of the few ways to restore normal operation of all the vital organs and systems is the use of metabolic therapy.

The aim of the work was to investigate the effectiveness of a course of treatment for metabolic drug meldonium to correct prooxidant-antioxidant and trophologic disorders in patients with comorbid course of chronic pancreatitis (CP) and stable coronary artery disease (SCAD).

Materials and Methods. The study included 90 patients with CP combined with SCAD who were divided into two groups (depending on treatment programs): I group (45 patients) received the standard treatment (ST); II group (45 patients) except ST received drug meldonium (Vazonat) with sequential introduction as follows: first grade - $5 \mathrm{ml}$ intravenous bolus injection 1 per day for 10 days; the second stage - the introduction of meldonium electrophoresis on a part of the left upper quadrant a day for 15 days; third degree - taking the drug further 2 capsules 1 time per day for a month.

Results. It was proved that the addition to the treatment of patients with comorbidity CP and SCAD meldonium with sequential introduction is more conducive to improving the performance and trophological pro-oxidant-antioxidant states than the standard basic therapy.

KEY WORDS: chronic pancreatitis; stable coronary heart disease; metabolic therapy; meldonium; sequential introduction.

Отримано 02.02.2017 